\title{
Internal Control Systems and Quality of Financial Reporting in Insurance Industry in Nigeria
}

\author{
Owolabi Sunday Ajao', Amosun Olayemi Oluwadamilola ${ }^{2, *}$ \\ ${ }^{1}$ Department of Accounting, Babcock University, Ilisan-Remo, Nigeria \\ ${ }^{2}$ Department of Accounting and Finance, Chrisland University, Abeokuta, Nigeria \\ Email address: \\ owolabis@babcock.edu.ng(O.S. Ajao), moyosolorunamosun@gmail.com (A. O. Oluwadamilola) \\ ${ }^{*}$ Corresponding author
}

\section{To cite this article:}

Owolabi Sunday Ajao, Amosun Olayemi Oluwadamilola. Internal Control Systems and Quality of Financial Reporting in Insurance Industry in Nigeria. Journal of Finance and Accounting. Vol. 8, No. 5, 2020, pp. 212-220. doi: 10.11648/j.jfa.20200805.12

Received: July 19, 2020; Accepted: August 17, 2020; Published: September 17, 2020

\begin{abstract}
In recent years many organizations have realized the importance of the role of directors, audit committee, internal auditors and external auditors in preparing and presenting quality financial reports to all stakeholders. In Nigeria, the performance and the quality of financial reports of companies in the insurance industry is dependent on the efficiency and effectiveness of the internal control system. This paper studied the impact of internal control systems and the quality of financial reporting in insurance industry in Nigeria. The research employed a survey research design. The study administered 100 questionnaires randomly to respondents, 98 questionnaires were returned and analysed. The data collected were analysed using descriptive and inferential statistics. The research hypothesis were analysed using regression analysis using Statistical Product and Service Solutions (SPSS 26). The results of the findings revealed that control environment, risk assessment, control activities, information and communication and monitoring has a statistical significant positive effect on quality of financial reporting of insurance industry in Nigeria. The study concluded that effective and efficient internal control system can affect the quality of financial reports of insurance industry in Nigeria.
\end{abstract}

Keywords: Internal Control System, Quality of Financial Reporting, Insurance Industry

\section{Introduction}

The role of the board of directors, audit committees, management and internal and external auditors in financial reporting cannot be over emphasized. Organizations have key goals that are deemed attainable. Profit making firms have a key goal to maximize key players' resources, while nonprofit making organizations key goal is to satisfy their client's social needs. In order to achieve these goals, supervision plays an important role in very organization.

Scandals such as the Waste Management 1998, Enron 2001, WorldCom 2002, AIG 2005, Cadbury Nigeria 2006 and BHS 2016 to mention a few have revealed situations where companies are engaging in unethical practices by omitting vital information or doctoring the financial information to cover up fraudulent activities that have occurred. These scandals have damaged investors' confidence on capital market. The occurrence of accounting scandals was caused by poor internal control system within the company [2]. These scandals have triggered tighter regulations and enhanced standards for accounting, auditing and corporate governance globally.

Internal control is concerned with the controls operative in every area of corporate activity as well as with the way in which individual controls inter-relate [10]. Internal auditors play a key role in monitoring a company's risk profile and identifying area to improve risk management. Internal auditing is intended to increase the efficiency and effectiveness of an organization through constructive criticism. Many organizations have realized the importance of internal audit. Greater attention is now focused on internal audit. Internal auditing can be defined as a managerial control which actually functions by appraising the effectiveness of the control.

For a company's internal control system to be effective management requires the use of judgement. Management and the board of directors use judgement to determine how much 
control is enough in the organization. The management and other personnel's use judgement to select, develop and deploy controls across the organization on a daily basis. Management and internal auditors also use judgement as they monitor, assess and test the effectiveness of the internal control system. External auditors also make use of judgement as they check and ascertain the effectiveness of the systems of internal control of their clients [10].

Internal control in every organization is very important as it contributes to the decision-making quality of firms, by providing reassurances that decisions made based on the financial information provided are reliable, that assets are correctly valued and protected and that key duties are executed correctly every point in time. Without effective internal control systems, essential goal-setting, strategy processes and organizational communication processes of organizations may be threatened, as underlying information processes may be compromised [3].

Effective internal control over financial reporting provides assurance regarding the credibility of financial reporting and the preparation of financial statements for external purposes. When one or more material weaknesses exist, the company's internal control cannot be deemed effective. The internal control system is recognized as a valuable monitoring mechanism employed by auditors (internal and external) to ensure the credibility of financial reporting [17].

The internal control system is comprised of various policies and procedures that helps in safeguarding the assets of a company, provide reliable financial reports, enhance a company's adherence with the rules and regulations stated in various standards and also enable management achieve effective and efficient operations [25].

The performance and quality of financial reports of private and public insurance companies in Nigeria are dependent on the effectiveness and efficiency of the internal control systems of these organizations. Companies in the Nigerian insurance industry have the potential for growth. Being mindful of the importance of the internal control system in the industry, the National Insurance Commission (NAICOM) issued a code of business ethics and a code of good corporate governance for the insurance industry in Nigeria. The code of conduct states the principles on internal control procedures and risk management functions which will bring significant improvement to the financial report, financial stability of the industry.

The intractable problems of risks and eventualities has been the biggest challenge of the Nigerian insurance industry. In recognition of this situation, the Nigerian government has attached great importance to the quality and efficiency of the insurance industry.

The companies in the insurance industry in Nigeria are incorporated by law to undertake operations in any of the following: life, non-life, re-insurance, brokerage and loss adjuster. As at May 2020, the insurance sector in Nigeria is made up of 13 composite (life and non-life) insurance companies, 28 general (non-life) insurance companies, 14 life insurance companies, 2 takaful insurance companies, 2 re-insurance companies, 457 licensed insurance brokerage companies, 34 licensed loss adjuster companies and over 200 licensed agents. These companies are regulated by the Insurance Act 2003 in Nigeria.

The Insurance Act 2003 serves as the rules and regulations for governing the activities of companies in the insurance industry. NAICOM was established by the National Insurance Commission Act 1997 with the goal of ensuring the effective administration, supervision, regulation and control of insurance business in Nigeria as well as the protection of insurance policyholders, beneficiaries and third parties to insurance contracts.

\section{Literature Review}

\subsection{Definition of Concepts}

\subsubsection{Internal Control Systems}

Internal control systems are the combined methods, plans and procedures which safeguard the assets of a firm enhance financial and operational performance as well as foster observance of policies that are prescribed [15].

Internal control systems is defined as a process for assuring achievement of an organization's objectives in operational effectiveness and efficiency, reliable financial reporting, and compliance with laws, regulations and policies. Internal control systems are defined as a set of organizational procedures and policies that ensure that all transactions are processed in the proper way in order to avoid theft, waste and misuse of an organisation's resources [23].

Internal control system is an obligatory requirement which helps the management to meet the obligations of corporate governance and other legislation [26]. Directors and management are required to have effective control over the resources and procedure of work within the organization. An affective internal control system gives the management the possibilities to prevent, detect and react against all the associated risks that arise as a result human behaviour or business operations.

\subsubsection{Internal Control}

Internal control is defined as a process effected by an entity's board of directors, management and other personnel, designed to provide assurance regarding the achievement of the objectives relating to the operations, reporting and compliance [10].

Internal control is defined as "The whole system of controls, financial and otherwise, created by the management so as to foster the business of the venture, in an organized and proficient manner, ensure adherence to management policies and also safeguard the assets and secure the completeness and accuracy of the records [5].

Internal control is also defined as the total system of control, financial and otherwise established by the management in order to ensure the business of the enterprise is done in an orderly and efficient manner as well as safeguard the assets and ensure the completeness and accuracy of the records [29]. According to the COSO 
framework, internal controls are categorized into 5 components, namely: control activities, risk assessment, control environment, information and communication, and monitoring activities.

\section{i. Control Activities}

Control activities are the policies and procedures that help ensure that management directives are implemented [5]. Control activities whether automated or manual, have various objectives and are applied and are various objectives and are applied at various organizational and functional levels.

Control activities are measures that help ensure that necessary actions are taken to address risks to the realization of an entity's objectives [9]. Control activities include policies governing underwriting policy, fulfilment of the solvency requirement as well as information systems.

Control activities are seen as the actions established through policies and procedures that help ensure that management directives to mitigate risks to the achievement of objectives are carried out. They are preventive or detective in nature and encompass arrange of manual and automated activities (authorization approvals, verification, reconciliation and business performance reviews) [10].

Control tasks are described as the actions that are established through policies and procedures to help ensure that management's directives to manage risks and achieve objectives are carried out, including the use of technology to conduct business activities [32].

\section{ii. Control Environment}

Control environment is defined as the set of standards, processes and structures that provide the basis for carrying out internal control across the organization [10]. The control environment comprises of the integrity and ethical values of the organization, the parameters enabling the board of directors to carry out its governance oversight responsibilities, the organizational structure and assignment of authority and responsibility, the process for attracting, developing and retaining skilled individuals and the consistency of performance measures, incentives and rewards to drive accountability for performance. The control environment has an impact on the overall system of internal control.

Control environment is seen as the foundation of the internal control systems and it sets the tone at the top, influencing the control consciousness of all staffs of an organization [27]. Control environment is also defined as the style, philosophy, and supportive attitude, in addition to the ethical values, competence, morale and integrity of those involved with the organization [20].

\section{iii. Risk Assessment}

Risk is defined as the possibility that an event will occur and adversely affect the achievement of objectives. Risk assessment is defined as a dynamic and iterative process for identifying and assessing risks to the achievement of objectives. Risk assessment forms the foundation for defining how risks will be managed [10].
Risk assessment is defined as the identification and analysis of management relevant risk to the preparation of financial statements [30]. Risk assessment is also defined as the identification and analyzing of relevant risks to the achievement of objectives, forming a basis for how the risks should be managed. Thus, setting objectives is a precondition to internal controls [14].

\section{iv. Information and Communication}

Information and communication refers to the process of identifying, capturing, and communicating of relevant information in an appropriate manner and within timeframe in order to accomplish the financial reporting objectives [8].

Information is seen as a necessary tool for an entity to carry out internal control responsibilities to support the achievement of its objectives [10]. Management obtains and makes use of relevant and quality information gotten from external and internal sources that support the functioning of the other components of internal control. Communication is defined as the continual, iterative process of providing, sharing and obtaining necessary information. Communication can be internal and external.

\section{v. Monitoring Activities}

Monitoring is a critical part of a complete internal control system. Monitoring aids management in determining how efficacious the internal controls put in place are. Monitoring also helps management know if the internal control systems are properly designed and functioning. Internal controls need to be monitored.Management should assess the quality of control performance on a timely basis. Monitoring involving the process of assessing the design of controls and their operation on a timely basis and taking necessary corrective actions [5].

\subsubsection{Quality of Financial Reporting}

The chief objective of financial reporting is to provide the users of the report information about the economic resources, claims and changes in resources and claims. These users who are present and potential investors, lenders and other creditors make use of the information to make decisions about buying, selling or holding equity or debt instruments. The users also need the financial information about the resources of the company in order to determine the efficient and effective use of the organizations existing resource by management [18].

The quality of financial reporting can be measured using he qualitative characteristics of financial information. These qualitative characteristics are grouped into two namely; fundamental qualitative characteristic and enhancing qualitative characteristics.

Fundamental qualitative characteristics are categorized into relevance and faithful representation. While the enhancing qualitative characteristics are categorized into comparability, verifiability, timeliness and understandability [18].

\section{i. Relevance}

Relevant financial information is capable of making a 
difference in the decisions made by users. Information has the capacity to make a difference in a decision making process of the end users. Financial information make a difference in decisions if it has predictive value, confirmatory value or both. Financial information is predictive in value if it can be used as an input to predict future outcomes. It is confirmatory in value if it provides feedback about previous evaluations [18].

\section{ii. Faithful Representation}

Financial reports represent economic phenomena in words and numbers. For financial information to be useful to the users it must represent relevant phenomena and must also faithfully represent the substance of the economic phenomena that it purports to represent. Financial reports must be complete, neutral, and free from error and understandable [18].

\section{iii. Comparability}

Comparability is the qualitative characteristic that enables users to identify and understand similarities in, and differences among, items. Financial information about a reporting entity is more useful when it can be compared with similar financial information about other entities and when it is compared with similar information about the same entity for another accounting period or another accounting date [18].

\section{iv. Verifiability}

Verifiability helps to reassure the end users that the financial information faithfully represents the economic phenomena it purports to represent. This means that different well-informed and independent observers can reach a consensus, although may not necessarily completely agree, that a particular depiction is a faithful representation. Verification can be direct or indirect. Direct verification is done through direct observation, while indirect verification is done by checking the financial inputs into a model or formula and then recalculating the outputs using the same methods the company used [18].

\section{v. Timeliness}

Timeliness refers to having information available to decision-makers in time to be capable of impacting their decisions [18]. This involves having information available to decision makers before losing relevance. This means, information must be readily available to influence decisions that users intend to make.

\section{vi. Understandability}

Understandability is the process of classifying, characterizing and presenting financial information in a clear and concise manner. Financial reports are to be prepared in a way that users who have a reasonable knowledge of business and economic activities and who review and analyse the information diligently can understand [18].

\subsection{Empirical Review}

The study [22] carried out a study on effect of internal control systems on financial performance of higher education institutions in Puntland. In his study, the researcher examined the relationship between internal control systems and performance of educational institutions. The researcher measured internal control using information and communication systems, internal audit and monitoring. The study revealed there is a significant positive relationship between internal control system and financial performance in institutions of higher learning in Puntland.

The study [21] examined the effect of internal control environment on the financial performance of companies quoted in the Nairobi Securities Exchange. The result of their investigation shows that there is a significant association between internal control environment and financial performance. The study [16] conducted a research on the impact of internal control systems on financial performance: the case of health institutions in upper west region of Ghana. The results of their findings revealed a positive association between internal controls and financial effectiveness.

The study [28] investigated the impact of internal control systems on the quality of bank's financial statements in Jordan. The results of the study revealed that internal control systems has a positive effect on the quality of financial reporting of banks in Jordan. The study [24] examined the effect of internal controls on financial accountability in the public sector in Nigeria. The study revealed that control environment, risk assessment and control activity has a positive significant effect on financial accountability in public sector.

The study [31] conducted a study on internal control systems on the quality of financial statement information and financial accountability in primary schools in Bandung, Indonesia. The findings showed control environment and control activities have significant influence on the quality of financial statement information which has significant influence on the quality of financial accountability in primary schools.

The study [11] investigated the effect of internal controls on financial reporting quality in Iranian family firms. The findings revealed that weakness in internal controls has a significant negative relationship with financial reporting quality.

The study [1] studied the impact of internal control system on financial accountability. The results of the research revealed that internal control system has a positive influence on financial accountability in civil service.

The study [4] conducted a study on the effect of internal control systems on the performance of companies in the Ghanian insurance industry. The findings revealed internal control systems has a statistical significant effect on the level of performance.

\section{Theoretical Framework}

\subsection{Theories}

\subsubsection{Agency Theory}

Agency Theory has its roots in economic theory which was postulated by Alchain and Demsetz in 1972 and was further developed by Jensen and Meckling (1976). The 
Agency theory is defined as "the relationship between the principals, such as shareholders and agents such as the company executives and managers". In this theory, it is believed that the shareholders (owners or principals of the company) hire the agents to work. The principals' delegate the running of business to the agents (directors or managers) who ensure the objectives of the shareholders are met [7].

The theory posits that agents have more information than principals and that this information asymmetry adversely affects the principals' ability to monitor whether or not their interests are being properly served by agents. The applicability of this theory to internal control and quality of accounting was tested by Cao Thi Thanh and Cheung in 2010 who relied on this theory to test the quality of internal control reporting and the quality of accounting. They observed that quality internal controls minimize information asymmetry through quality reporting. Quality internal control system will enhance transparency in reporting and diminish agency cost.

\subsubsection{Stewardship Theory}

Stewardship theory has its origins in psychology and sociology and was intended for researchers to study situations were executives who are stewards are motivated to act in the best interests of their principals [13]. This theory centres on the issues concerning the stakeholders in an institution. It requires that corporate entities always seeks to provide a balance between the interests of its different stakeholders in order to ensure that each interest receives some degree of satisfaction (Abrams, 1951). This theory argues that the managers or executives of a company are stewards of the owners, and both groups share common goals.

\subsubsection{Contingency Theory}

The contingency theory of leadership and management was proposed by Fred Fiedler in 1964. Contingency theory is an organizational theory that claims that there is no one best way to organize a corporation, to run a company or to make decisions. However, the best course of action is dependent upon the internal and external situation of the organization. The contingency theory of leadership and management states that there is no standard way by which an organization can be led, organized and managed. Organizations and their functions are dependent on various external and internal factors. The functions of audits are affected by various factors (internal and external) in the environment.

\subsubsection{Attribution Theory}

Attribution theory is a social psychology theory that discovers how people interpret events and behaviours and how they ascribe causes to the events and behaviours. This theory was proposed by Fritz Heider in 1958. Attribution theory advocates for auditors to report on the effectiveness of firms' internal control. Auditors are therefore expected to gain a better understanding of the internal controls in place, assess the design and implementation of the internal controls, and test the operating effectiveness of the internal controls.

\subsection{Methodology}

This study adopted a quantitative survey research design using structured questionnaires. The study is limited to companies in the insurance industry in Nigeria. Simple random sampling technique was used to determine the sample size. 100 questionnaires were sent out to respondents, however, 98respondents filled the online survey. Data for this research were sourced form primary source for both internal control systems and quantity of financial reporting measures. A 5 point Likert scale was adopted as a scale of measurement for this study. Data was analysed through the use of descriptive statistics and inferential statistics.

\subsection{Hypothesis}

In order to test the effect of internal control systems on quality of financial reporting in insurance industry in Nigeria, the following null hypothesis were established:

$\mathrm{H}_{0} 1$ : There is no statistically significant relationship between control environment and the quality of financial reporting in the Nigerian Insurance Industry.

$\mathrm{H}_{0}$ 2: There is no statistically significant relationship between control activities and the quality of financial reporting in the Nigerian Insurance Industry

$\mathrm{H}_{0} 3$ : There is no statistically significant relationship between risk assessment and the quality of financial reporting in the Nigerian Insurance Industry

$\mathrm{H}_{0} 4$ : There is no statistically significant relationship between information and communication and the quality of financial reporting in the Nigerian Insurance Industry

$\mathrm{H}_{0} 5$ : There is no statistically significant relationship between monitoring and the quality of financial reporting in the Nigerian Insurance Industry.

\section{Data Analysis and Interpretation}

\subsection{Data Analysis}

The result of the data analysis is shown in Appendix 1.

\subsection{Interpretation}

In order to test for the reliability of the questions, the questionnaires were subject to a reliability test of internal consistency using Cronbach's Alpha. Cronbach's Alpha amounts to 0.975 which indicates that the measurements used are reliable.

The results of the regression analysis adopted to test the hypothesis one to five is shown in tables $1-5$ and is interpreted as follows:

Table 1 depicts an assessment of statistical significance of the result. This is a test of the null hypothesis to enable the determination of whether or not the null hypothesis should be accepted or rejected. From the coefficient table, the significance value in this study is 0.000 , which is lower than the cut-off of $p<0.05$. This therefore signifies that there is a statistical significant relationship between control environment and quality of financial reporting. From Table 4, 
the $R$ value is 0.777 , when expressed in percentage terms; it shows that this model explains $77.7 \%$ of the variance in the dependent variable being quality of financial reporting. That is to say, the remaining $22.3 \%$ variation in the dependent variable can be explained outside the independent variable by other factors.

Table 1. Control Environment and Quality of Financial Reporting.

\begin{tabular}{|c|c|c|c|c|c|c|c|}
\hline \multicolumn{8}{|c|}{ Model Summary } \\
\hline Model & $\mathbf{R}$ & R Square & Adjusted R Square & Std. Error of the Estimate & & & \\
\hline $\begin{array}{ll}1 \\
\text { ANOVA }\end{array}$ & $.777^{\mathrm{a}}$ & .604 & .600 & 4.496 & & & \\
\hline Model & & Sum of Squares & & Df & $\begin{array}{l}\text { Mean } \\
\text { Square }\end{array}$ & $\mathrm{F}$ & Sig. \\
\hline & Regression & 2964.076 & & 1 & 2964.076 & 146.635 & $.000^{\mathrm{b}}$ \\
\hline 1 & $\begin{array}{l}\text { Residual } \\
\text { Total }\end{array}$ & 1940.547 & & 96 & 20.214 & & \\
\hline Coeffici & & & & & & & \\
\hline Model & & $\begin{array}{l}\text { Unstandardized Coefficients } \\
\text { B }\end{array}$ & Std. Error & $\begin{array}{l}\text { Standardized Coefficients } \\
\text { Beta }\end{array}$ & $\mathrm{t}$ & Sig. & \\
\hline 1 & $\begin{array}{l}\text { (Constant) } \\
\text { ConEnv }\end{array}$ & $\begin{array}{l}12.014 \\
3.781\end{array}$ & $\begin{array}{l}4.420 \\
.312\end{array}$ & .777 & $\begin{array}{l}2.718 \\
12.109\end{array}$ & $\begin{array}{l}.008 \\
.000\end{array}$ & \\
\hline
\end{tabular}

a. Predictors: (Constant), ConAct b. Dependent Variable: FinRep.

Table 2 depicts an assessment of statistical significance of the result. This is a test of the null hypothesis to enable the determination of whether or not the null hypothesis should be accepted or rejected. From the coefficient table, the significance value in this study is 0.000 , which is lower than the cut-off of $p<0.05$. This therefore signifies that there is a statistical significant relationship between control activities and quality of financial reporting in the insurance industry in Nigeria. The $R$ value is 0.825 , when expressed in percentage terms; it shows that this model explains $82.5 \%$ of the variance in the dependent variable being quality of financial reporting. That is to say, the remaining $17.5 \%$ variation in the dependent variable can be explained outside the independent variable by other factors.

Table 2. Control Activities and Quality of Financial Reporting.

\begin{tabular}{|c|c|c|c|c|c|c|}
\hline \multicolumn{7}{|c|}{ Model Summary } \\
\hline Model & $\mathbf{R}$ & R Square & Adjusted R Square & Std. Error of the Estimate & & \\
\hline 1 & $.825^{\mathrm{a}}$ & .680 & .677 & 4.042 & & \\
\hline \multicolumn{7}{|c|}{ ANOVA $^{\text {a }}$} \\
\hline \multirow[t]{2}{*}{ Model } & & Sum of Squares & Df & Mean Square & $\mathrm{F}$ & Sig. \\
\hline & Regression & 3335.988 & 1 & 3335.988 & 204.161 & $.000^{\mathrm{b}}$ \\
\hline \multirow[t]{2}{*}{1} & Residual & 1568.635 & 96 & 16.340 & & \\
\hline & Total & 4904.622 & 97 & & & \\
\hline Model & & $\begin{array}{l}\text { Unstandardized Coefficients } \\
\text { B }\end{array}$ & Std. Error & $\begin{array}{l}\text { Standardized Coefficients } \\
\text { Beta }\end{array}$ & $\mathrm{t}$ & Sig. \\
\hline \multirow{2}{*}{1} & (Constant) & 11.291 & 3.799 & & 2.972 & .004 \\
\hline & ConAct & 3.843 & .269 & .825 & 14.289 & .000 \\
\hline
\end{tabular}

a. Predictors: (Constant), ConAct b. Dependent Variable: FinRep.

Table 3 depicts an assessment of statistical significance of the result. This is a test of the null hypothesis to enable the determination of whether or not the null hypothesis should be accepted or rejected. From the coefficient table, the significance value in this study is 0.000 , which is lower than the cut-off of $p<0.05$. This therefore signifies that there is a statistical significant relationship between risk assessment and quality of financial reporting in the insurance industry in Nigeria. The $R$ value is 0.842 , when expressed in percentage terms; it shows that this model explains $84.2 \%$ of the variance in the dependent variable being quality of financial reporting. That is to say, the remaining $15.8 \%$ variation in the dependent variable can be explained outside the independent variable by other factors.

Table 3. Risk Assessment and Quality of Financial Reporting.

\begin{tabular}{|c|c|c|c|c|c|c|}
\hline \multicolumn{7}{|c|}{ Model Summary } \\
\hline Model & $\mathbf{R}$ & R Square & Adjusted R Square & Std. Error of the Estimate & & \\
\hline \multicolumn{6}{|l|}{ ANOVA $^{\mathrm{a}}$} & \\
\hline \multirow[t]{2}{*}{ Model } & & Sum of Squares & Df & Mean Square & $\mathrm{F}$ & Sig. \\
\hline & Regression & 3477.025 & 1 & 3477.025 & 233.815 & $.000^{\mathrm{b}}$ \\
\hline 1 & $\begin{array}{l}\text { Residual } \\
\text { Total }\end{array}$ & $\begin{array}{l}1427.598 \\
4904.622\end{array}$ & $\begin{array}{l}96 \\
97\end{array}$ & 14.871 & & \\
\hline Coefficien & & & & & & \\
\hline
\end{tabular}




\begin{tabular}{|c|c|c|c|c|c|c|}
\hline \multicolumn{7}{|c|}{ Model Summary } \\
\hline Model & $\mathbf{R}$ & R Square & Adjusted R Square & Std. Error of the Estimate & & \\
\hline \multirow{2}{*}{ Model } & & \multicolumn{2}{|c|}{ Unstandardized Coefficients } & \multirow{2}{*}{$\begin{array}{l}\text { Standardized Coefficients } \\
\text { Beta }\end{array}$} & \multirow{2}{*}{$\mathrm{t}$} & \multirow{2}{*}{ Sig. } \\
\hline & & $\mathrm{B}$ & Std. Error & & & \\
\hline \multirow{2}{*}{1} & (Constant) & 10.982 & 3.571 & & 3.076 & .003 \\
\hline & RisAss & 3.818 & .250 & .842 & 15.291 & .000 \\
\hline
\end{tabular}

a. Predictors: (Constant), RisAss b. Dependent Variable: FinRep

Table 4 depicts an assessment of statistical significance of the result. This is a test of the null hypothesis to enable the determination of whether or not the null hypothesis should be accepted or rejected. From the coefficient table, the significance value in this study is 0.000 , which is lower than the cut-off of $p<0.05$. This therefore signifies that there is a statistical significant relationship between information and communication and quality of financial reporting in the insurance industry in Nigeria. The $R$ value is 0.833 , when expressed in percentage terms; it shows that this model explains $83.3 \%$ of the variance in the dependent variable being quality of financial reporting. That is to say, the remaining $16.7 \%$ variation in the dependent variable can be explained outside the independent variable by other factors.

Table 4. Information and Communication and Quality of Financial Reporting.

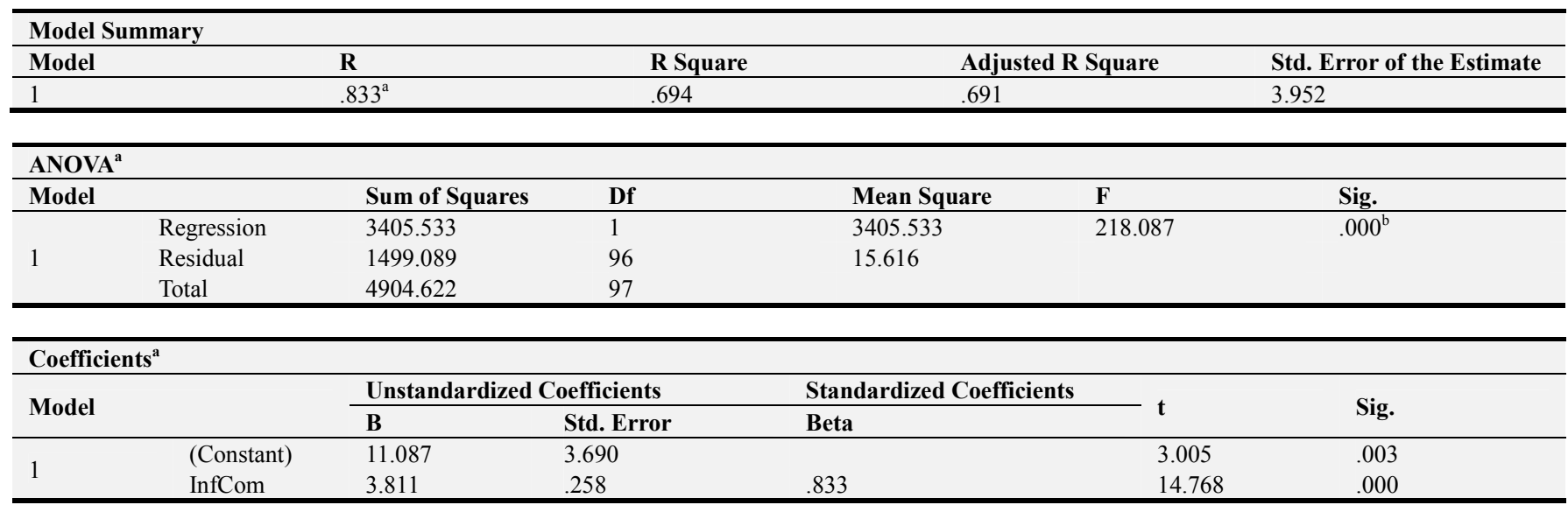

a. Predictors: (Constant), InfCom b. Dependent Variable: FinRep

Table 5 depicts an assessment of statistical significance of the result. This is a test of the null hypothesis to enable the determination of whether or not the null hypothesis should be accepted or rejected. From the coefficient table, the significance value in this study is 0.000 , which is lower than the cut-off of $p<0.05$. This therefore signifies that there is a statistical significant relationship between monitoring and quality of financial reporting in the insurance industry in Nigeria. The $R$ value is 0.761 , when expressed in percentage terms; it shows that this model explains $76.1 \%$ of the variance in the dependent variable being quality of financial reporting. That is to say, the remaining $23.9 \%$ variation in the dependent variable can be explained outside the independent variable by other factors.

Table 5. Monitoring and Quality of Financial Reporting.

\begin{tabular}{|c|c|c|c|c|c|c|}
\hline \multicolumn{7}{|c|}{ Model Summary } \\
\hline Model & $\mathbf{R}$ & R Square & Adjusted R Square & \multicolumn{3}{|c|}{ Std. Error of the Estimate } \\
\hline 1 & $.761^{\mathrm{a}}$ & .579 & .575 & \multicolumn{3}{|c|}{4.636} \\
\hline \multicolumn{7}{|c|}{ ANOVA $^{\mathrm{a}}$} \\
\hline \multicolumn{2}{|c|}{ Model } & Sum of Squares & Df & Mean Square & $\mathbf{F}$ & Sig. \\
\hline \multirow{3}{*}{1} & Regression & 2840.909 & 1 & 2840.909 & \multirow{3}{*}{132.154} & \multirow{3}{*}{$.000^{\mathrm{b}}$} \\
\hline & Residual & 2063.714 & 96 & 21.497 & & \\
\hline & Total & 4904.622 & 97 & & & \\
\hline \multicolumn{7}{|c|}{ Coefficients $^{\mathrm{a}}$} \\
\hline \multirow[t]{2}{*}{ Model } & & \multicolumn{2}{|c|}{ Unstandardized Coefficients } & $\begin{array}{l}\text { Standardized } \\
\text { Coefficients }\end{array}$ & \multirow[t]{2}{*}{$\mathbf{T}$} & \multirow[t]{2}{*}{ Sig. } \\
\hline & & B & Std. Error & Beta & & \\
\hline \multirow{2}{*}{1} & (Constant) & 23.721 & 3.643 & & 6.511 & .000 \\
\hline & Moni & 3.033 & .264 & .761 & 11.496 & .000 \\
\hline
\end{tabular}

a. Predictors: (Constant), Moni b. Dependent Variable: FinRep 
In general terms, the study concluded that internal control systems (control environment, risk assessment, control activities, information and communication and monitoring) have an effect on the quality of financial reports insurance companies produce. This conclusion supports the studies examined by the studies $[16,4,1]$ and [28].

\section{Discussion of Findings}

The main objective of this paper is to ascertain the degree of the relationship between the internal control and the quality of quality of financial reporting. The study measured the effect of control environment, risk assessment, control activities, information and communication and monitoring on the quality of financial reports of insurance industry in Nigeria. The results of the findings show that control environment, risk assessment, control activities, information and communication and monitoring have statistical significant impact on the quality of financial reporting of insurance industry in Nigeria. The results reveal that internal auditors bolster the quality of financial reports of insurance firms in Nigeria.

\section{Conclusion and Recommendation}

The study delved into the effect of internal control on the quality of financial reporting of insurance industry in Nigeria. From the findings, the research revealed that the internal control variables such as the control environment, risk assessment control activities, information and communication and monitoring have influence on the quality of financial reporting of insurance industry in Nigeria.

The findings also coroborates the fact that the internal control system in any establishment is immensely crucial as it has a direct impact on the quality of the financial report provided to the end users.

Management of insurance companies are encouraged to constantly review the internal control system of the organization and also ensure that competent personnel head the internal audit department of the establishment.

\section{References}

[1] Adeyemi, F., \& Olarewaju, O. (2019). Internal Control System and Financial Accountability: An Investigation of Nigerian South-Western Public Sector. ACTA UNIVERSITATIS DANUBIUS, 15 (1).

[2] Agrawal, A., \& Chadha, S. (2005). Corporate Governance and Accounting Scandals. The Journal of Law \& Economics, 48 (2), 371-406. Doi: 10.1086/430808.

[3] Amussah, A. (2017). Effect of internal control systems on performance of companies in the insurance industry in Ghana (Masters Dissertation, University of Cape Cost).

[4] Arwinge, Olof (2013). Internal Control: A Study of Concept and Themes. Springer- Verlag Berlin Heldelberg.
[5] Association of Accountancy Bodies in West Africa (ATSWA) (2009). Principles of Auditing. Study Pack.

[6] Cao Thi Thanh, H., \& Cheung, T. (2010). Internal control reporting and accounting quality: Insight comply or explain internal control regime. (Master's thesis, Umea University, Sweden). Retrieved from http://divaportal.org/smash/get/diva2:326919/full text01.pdf.

[7] Clark, T. (2004) "Theories of Corporate Governance: The Philosophical Foundations of Corporate Governance" London and New York: Routledge.

[8] Colbert, J. L., \& Aldridge, C. R. (1994). How to report on internal control under COSO. Journal of Corporate Accounting \& Finance, 6 (2), 99-106. doi: 10.1002/jcaf.3970060210.

[9] Committee of European Insurance and Occupational Pensions Supervisors (2003). Internal control for insurance undertakings. Retrieved from: https://web.actuaries.ie/sites/default/files/ermresources/116_in ternational_control_insurance.pdf.pdf.

[10] Committee of Sponsoring Organizations of the Treadway Commission (COSO), (2013). Internal control-Integrated Framework-Executive Summary, May, 2013.

[11] Dashtbayaz, M. L., Salehi, M., \& Safdel, T. (2019). The effect of internal controls on financial reporting quality in Iranian family firms. Journal of Family Business Management. Doi: 10.1108/jfbm-09-2018-0047.

[12] Davis, J. H., F. D. Schoorman, and L. Donaldson. 1997. "Toward a Stewardship Theory of Management." Academy of Management Review 22 (1): 20-47. doi: $10.2307 / 259223$

[13] Donaldson, L., and J. H. Davis. 1991. "Stewardship Theory or Agency Theory: CEO Governance and Shareholder Returns." Australian Journal of Management 16 (1): 49-64. doi: $10.1177 / 031289629101600103$.

[14] Goodwin - Stewart, J., \& Kent, P. (2006). The use of internal audit by Australian companies. Managerial Auditing Journal, 21 (1), 81-101. doi: 10.1108/02686900610634775.

[15] Hopkin, P. (2012). Fundamentals of risk management: Understanding, evaluating and implementing effective risk management. London, UK: Kogan Page Publishers.

[16] Ibrahim, S., Diibuzie, G., \& Abubakari, M. (2017). The Impact of Internal Control Systems on Financial Performance: The Case of Health Institutions in Upper West Region of Ghana. International Journal of Academic Research in Business and Social Sciences, 7 (4). doi: 10.6007/ijarbss/v7i4/2840.

[17] Institute of Chartered Accountants of Nigeria (ICAN). (2015). Technical Guidance on Assurance Engagement to Report on Internal Control over Financial Reporting. Retrieved from: https://icanig.org/ican/documents/ICAN-F-R.pdf.

[18] International Accounting Standards Board (2018). Conceptual Framework for Financial Reporting.

[19] Jensen, M. C. and Meckling, W. (1976) "Theory of the Firm: Managerial Behaviour, Agency, Costs and Ownership Structure". Journal of Financial Economics, Vol. 3, pp. 305-360. 
[20] Jokipii, A. (2006). The structure and effectiveness of internal control: A contingency approach. (Doctoral dissertation, University of Vaasa, Finland). https://www.univaasa.fi/materiaali/pdf/isbn_952-476-161-0.pdf.

[21] Kinyua, J., Gakure, R., Gekara, M., \& Orwa, G. (2015). Effect of Internal Control Environment on the Financial Performance of Companies Quoted in the Nairobi Securities Exchange. International Journal of Innovative Finance and Economics Research, 3 (4), 29-48.

[22] Mohamed, H. (2016). Effect of internal control systems on financial performance of higher education institutions in Puntland. International Journal of Economics, Commerce and Management, $I V(12)$.

[23] Ndungu, H. (2013). The effect of internal controls on revenue generation: A case study of the University of Nairobi Enterprise and Services Limited. (Master's dissertation, University of Nairobi, Kenya).

[24] Oche, J., Agbe, I., \& Igbabee, U. (2018). Effect of internal control on financial accountability in the Nigerian public sector. KASU Journal of Accounting Research and Practice (KAJARP), 7 (1).

[25] Omane-Antwi, K. B. (2009). Auditing theory and practice: The auditing compendium. Tema, Ghana: Digibooks Ghana Ltd.
[26] Qaisar, A., \& Javid, I. (2012). Internal Control System: Analyzing Theoretical Perspective and Practices. Middle-East Journal of Scientific Research, 12 (4).

[27] Ramos, M. (2004). Evaluate the control environment: Documentation is only a start, now it's all about asking questions. Journal of Accountancy, 197 (5), 75-79.

[28] Salameh, R. (2019). What Is the Impact of Internal Control System on the Quality of Banks' Financial Statements in Jordan? Academy of Accounting and Financial Studies Journal, 23 (5).

[29] Saleemi N. A. (1989). Auditing Simplified. Saleemi Publishers, Nairobi.

[30] Sudsomboon, S., \& Ussahawanitchakit, P. (2009). Professional audit competencies: The effects on Thai's CPAS audit quality, reputation, and success. Review of Business Research, 9 (3), 66-85.

[31] Widyaningsih, A. (2016). Internal Control System on the Quality of Financial Statement Information and Financial Accountability in Primary Schools in Bandung, Indonesia. Research Journal of Finance and Accounting, 7 (10).

[32] WHO. (2013). Principles of internal control framework and their applicability to managers, general programme of work: WHO's long term global strategy document. 